\title{
Granite and associated mafic phases, North River pluton, Cobequid Highlands, Nova Scotia
}

\author{
Georgia Pe-Piper \\ Department of Geology, St. Mary's University, Halifax, Nova Scotia B3H 3C3, Canada
}

Date Received February 20, 1990

\begin{abstract}
The North River pluton is one of a series of upper Devonian - lower Carboniferous granite and gabbro/diorite plutons in the Cobequid Highlands. It lies within a regional zone of east-west strike-slip faulting associated with the Cobequid Fault. The pluton consists of a single main granite unit that intruded small marginal bodies of gabbro. The southern part of the pluton is locally foliated and pervasively fractured. Diabase and microgranite sheets and dykes cut the pluton and adjacent country rock. A relative sequence of intrusion can be determined from cross-cutting relationships with foliated or fractured granite. Hybrid rocks demonstrate that some of the mafic magma was intruded synchronously with granitic magma.

The pluton is geochemically similar to other Devono-Carboniferous plutons in the Cobequid Highlands, although it represents a deeper structural level than most of the other plutons. The granite is a subalkalic A-type granite. The mafic rocks show "within-plate" geochemical characteristics; early intrusions resemble olivine-normative continental tholeiites, but later dykes are highly fractionated and show strong enrichment in incompatible elements. Enrichment in Rb and $\mathrm{K}$ in the northeastem part of the pluton reflects a late metasomatic event associated with the growth of secondary biotite.

The Devono-Carboniferous plutons of the Cobequid Highlands differ from other published examples of shear zone plutonism in that magma generation appears to have been related to either local or more probably regional extension rather than the shear zone having tapped a magma that originally resulted from either subduction or continental collision.
\end{abstract}

Le pluton de North River est l'un des bâtis dévoniens supérieurs à carbonifêres inférieurs constituant une suite de plutons granitiques et gabbroïques/dioritiques présente dans les Monts Cobequid. Il gît au sein d'une zone régionale de décrochement est-ouest associée à la faille de Cobequid. Le pluton consiste en une unité principale unique de granite qui fit intrusion dans de petits bâtis gabbroïques marginaux. La portion méridionale du pluton montre une foliation locale et une fracturation pénétrative. Des lames ainsi que des filons de diabase et de microgranite recoupent le pluton et la roche encaissante adjacente. Les recoupements du granite folié ou fracturé permettent de déterminer une séquence relative d'intrusion. Des roches hybrides démontrent qu'une fraction du magma mafique fit intrusion au même moment que le magma granitique.

La géochimie du pluton est semblable à celle des autres plutons dévono-carbonifêres présents dans les Monts Cobequid, et ce bien qu'il représente un niveau structural plus profond que celui des autres plutons. Le granite est un granite subalcalin de type A. Les roches mafiques montrent des caractéristiques géochimiques “intraplaques"; les intrusions précoces ressemblent à des tholéiites continentales à olivine normative mais les filons plus tardifs ont subi un fractionnement prononcé et ils sont fortement enrichis en éléments incompatibles. Un enrichissement en $R b$ et en $K$ dans la région nord-est du pluton reflète un événement métasomatique tardif associé à la croissance d'une biotite secondaire.

Les plutons dévono-carboniferes des Monts Cobequid different des autres exemples publiés de plutonisme associé à une zone de cisaillement en ce que la venue du magma semble avoir été reliée à une extension locale ou, de façon plus vraisemblable, régionale plutôt qu'au captage par la zone de cisaillement d'un magma résultant à l'origine soit d'une subduction, soit d'une collision continentale.

[Traduit par le journal]

\section{INTRODUCTION}

The North River pluton (Donohoe and Wallace, 1982) is one of a series of plutons that intruded Avalon Terrane rocks immediately north of the Cobequid Fault (Fig. 1) and have yielded early Carboniferous Rb-Sr isochrons (Pe-Piper et al., 1989a) and latest Devonian zircon dates (Doig et al., 1990). The Cobequid Fault is part of the major fault zone (Cobequid-Chedabucto Fault zone, or Minas Geofracture) that marks the boundary between the Meguma and Avalon terranes of the Appalachian Orogen (Keppie,
1982). Large strike-slip motion occurred on the fault in the Devonian-Carboniferous. The plutons were emplaced at high structural levels, and are associated with basalts and rhyolites of the Fountain Lake Group (Pe-Piper et al., 1989a). The North River pluton consists principally of granite, with minor marginal gabbro, and has yielded aRb-Sr isochron date of $356 \pm 17 \mathrm{Ma}$ (PePiper et al., 1989a).

Plutons in the western Cobequid Highlands that are similar to the North River pluton include, from west to east, the Cape Chignecto pluton (Waldron et al., 1989), the Hanna Farm pluton 


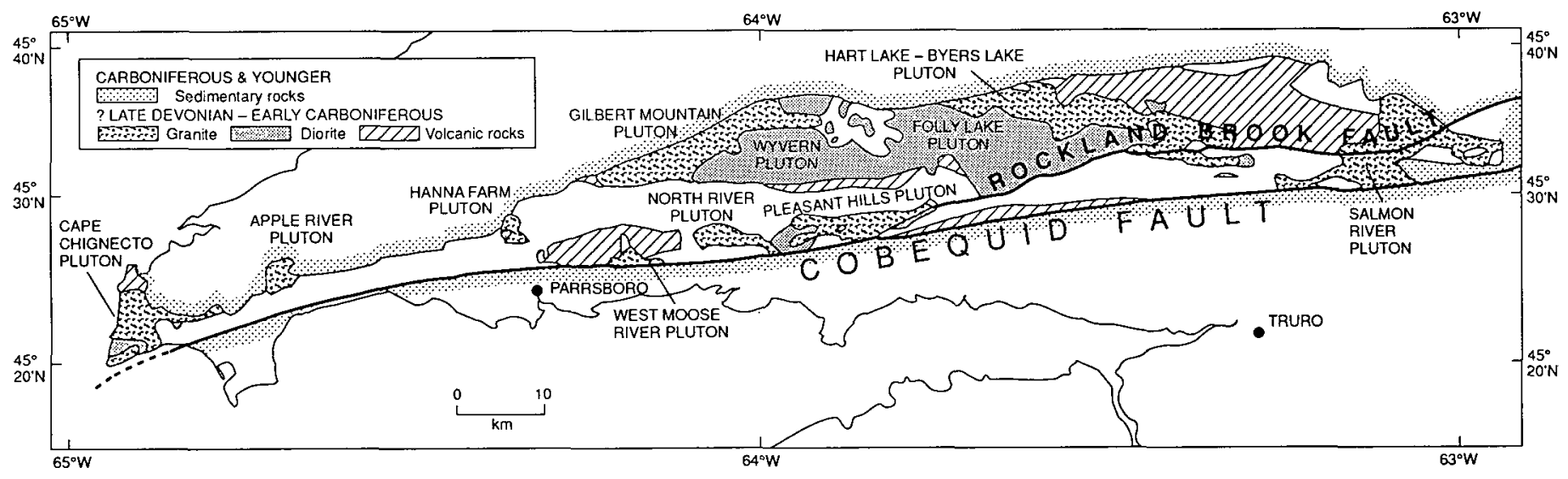

Fig. 1. Regional map of the Cobequid Highlands showing location of the North River pluton. Based on Murphy et al. (1988), Pe-Piper and Turner (1988) and Waldron et al. (1989).

(Pe-Piper and Turner, 1988), the West Moose River pluton (PePiper $e t$ al., in press), and the Pleasant Hills pluton (Pe-Piper $e t$ al., 1989b). All these plutons contain greater or lesser amounts of gabbro, diabase and diorite, some of which predated and some of which postdated granite intrusion. These plutons appear to have been synchronous with rhyolites and basalts of the Fountain Lake Group of the western Cobequid Highlands, which are geochemically similar to the granites and gabbro/diabase, respectively $(\mathrm{Pe}-$ Piper et al., 1989a, in press). The granites are A-type granites that lack peralkaline units; the gabbros resemble olivine-normative continental tholeiites (Pe-Piper et al., in press).

In this paper, the geology, petrography and geochemistry of the North River pluton are described and compared with other plutons in the westem Cobequid Highlands. Unusual features of the North River pluton are emphasised.

\section{GEOLOGY}

The North River pluton is well exposed in three southflowing rivers: North River, Bass River of Five Islands and East River. Larger tributaries also have good outcrops, but there is little exposure between them. The western margin of the pluton is well exposed in blueberry fields and along woods roads, but there are few outcrops near its eastern margin.

The main Cobequid Fault is situated about $1.5 \mathrm{~km}$ south of the North River pluton (Fig. 2), and is marked by a zone of intense deformation a few hundred metres wide that includes some slivers of deformed granite. South of the fault are sedimentary rocks of the lower Carboniferous Parrsboro Formation. North of the fault, the North River pluton intruded argillites of the Hadrynian Jeffers Group. The southeastern margin of the pluton is in probable faulted contact with a series of unfossiliferous sedimentary rocks mapped by Donohoe and Wallace (1982) as undivided Silurian-Devonian (Fig. 2). Several large east-west faults cut the Jeffers Group and these ?Siluro-Devonian sedimentary rocks between the Cobequid Fault and the pluton. In addition, faults trending north-south with significant dip-slip components juxtapose the different rock units south of the pluton.

The predominant lithology of the North River pluton is coarse-grained granite. At the extreme margin of the pluton, granite is fine grained (variably equigranular or porphyritic). A medium-grained granite is widespread in the extreme southwestem part of the pluton. The northern margin of the pluton is subvertical and the southern margin dips southward.

Gabbroic bodies, typically a few tens to a few hundred of metres in size, occur along many of the exposed margins of the pluton (with the exception of the northern margin), outcropping in East River and blueberry fields west of the river, Gundalow Brook, Bass River, North River and on the woods roads at the western margin of the pluton (Fig. 2). Rocks of intermediate composition, with textures suggesting a hybrid origin, are associated with the gabbros at the south margin of the pluton in North and Bass rivers. In North River, the gabbros are cut by granite veins and the granite becomes finer grained towards the contact with the gabbro. Near the contact, the hybrid rocks are restricted to a $30 \mathrm{~cm}$ wide zone, and include pods of granite within the gabbro. However, granitic veins and associated hybridisation are also seen within the main gabbro body. The hybrid rocks in Bass River are similar, but contacts with gabbro and granite are not exposed. West of East River, granite veins also cut gabbro. In East River the marginal gabbro appears chilled against the granite. In no other place is the contact visible between marginal gabbro and granite.

Both diabase-gabbro and microgranite sheets cut the pluton. Mafic dykes petrographically similar to those in the pluton are also found in the Jeffers Group immediately north and west of the pluton. Microgranite dykes are also common in the country rock around the pluton, and some are composite, with diabase margins. A few dykes consist of inhomogeneous (hybrid) rock of intermediate composition. Dykes are well exposed on Lynn road, $1 \mathrm{~km}$ west of the westem margin of the pluton. A complex zone of microgranite and diabase dykes some $350 \mathrm{~m}$ wide crops out in the North River just south of the pluton. Country rocks of the Jeffers Group make up less than $10 \%$ of this zone, which may therefore be a pull-apart feature.

The relative ages of mafic intrusions within the pluton can be determined from cross-cutting relationships with the granite and from the relative extent of deformation in the granite and the mafic intrusions. Much of the southern part of the pluton is pervasively fractured. Locally, there is a flat-lying foliation, best 


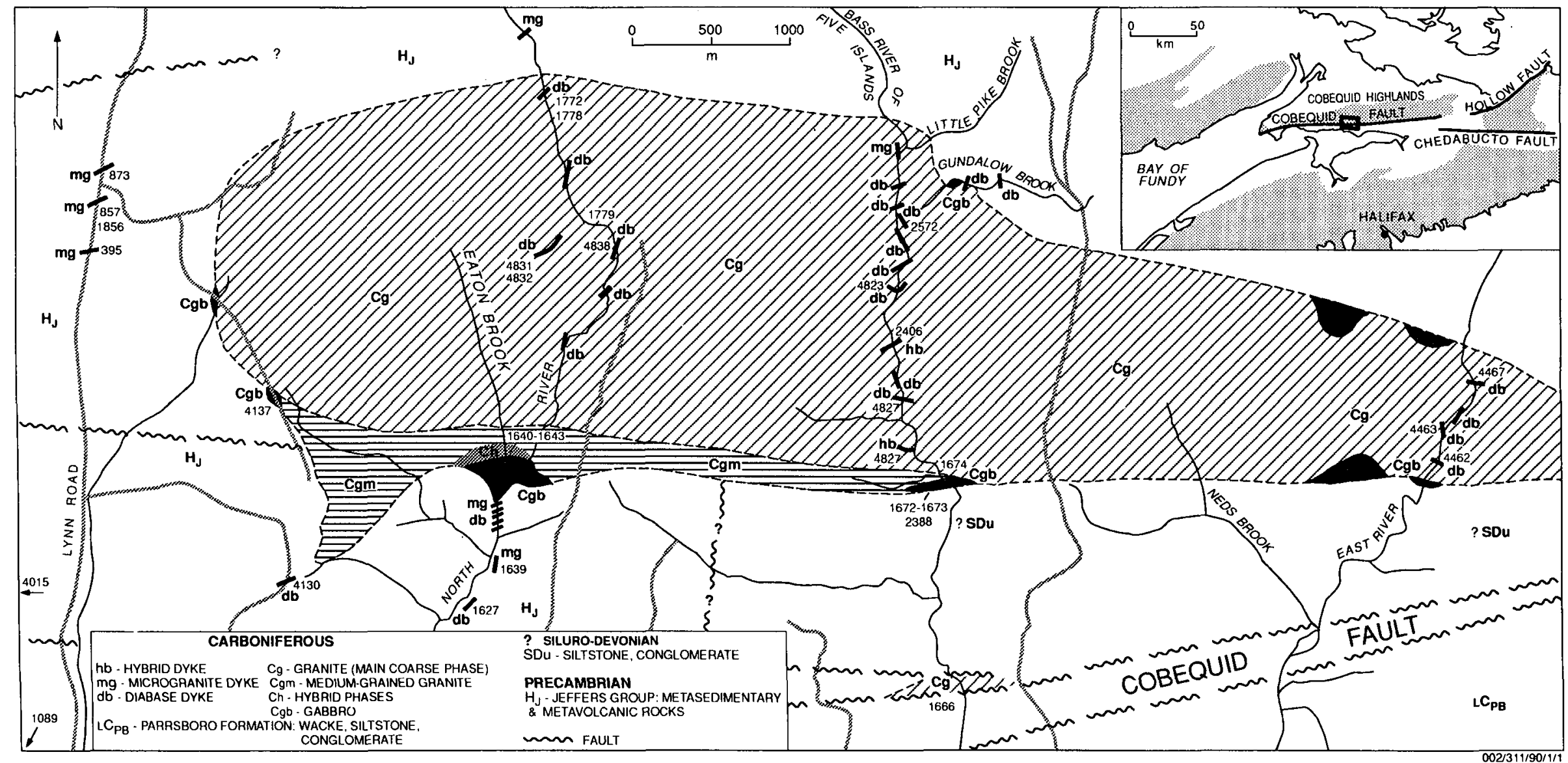

Fig. 2. Geological map of the North River pluton showing location of analysed samples. 
developed in mafic rocks. Three relative age groups of mafic rocks (early, intermediate, and late) are distinguished by these criteria (Table 1). (1) Some gabbro bodies at the southern margin of the pluton have been cut by granite veins. Granite appears to have mixed with the extreme outer rim of the gabbro, probably at a time when the gabbro was not completely consolidated. Within this gabbro, the dispersed occurrence of largely assimilated minor granite veins indicates either actual co-existence of contemporaneous felsic and mafic magmas, or intrusion of minor granite magma in veins into a plastic, almost fluid, mafic magma body. Mafic xenoliths represent early cooled pieces of gabbro caught up in the resulting hybrid magma. In this case, the mafic magma appears to have been contemporaneous with, or even to have predated, the granite. (2) Some mafic sheets appear to have been intruded prior to any deformation of the granite, and were later deformed with the granite. These include a foliated sheet in southern East River, the marginal gabbros in East River (which are chilled against the granite) and at the western edge of the pluton, and some rather deformed dykes. (3) Other mafic sheets cross cut some of the deformation (either foliation or closespaced fracturing) in the granite and are themselves commonly little deformed; these are interpreted to be the youngest mafic sheets (Table 1).

\section{PETROGRAPHY}

\section{Granitoid rocks}

The predominant coarse-grained unit of the North River pluton has a granophyric texture and consists of microperthite, quartz and plagioclase (Table 2). Plagioclase occurs as subhedral to anhedral grains and all those analysed by electron microprobe consist of albite. Microperthite in places appears to have replaced plagioclase and elsewhere is intergrown with cuniform or rodshaped quartz. Some microperthite is rimmed by albite. Large quartz crystals are mostly subhedral and rounded; texturally they appear earlier than feldspar and granophyric intergrowths. The granophyric texture commonly occurs as pod-like growths within the rock, in places nucleated around a smaller crystal of plagioclase, perthite or quartz. Most rocks contain less than 3\% mafic minerals, principally opaque oxides. The granites are ubiquitously fractured; green secondary biotite occurs along the fractures, together with muscovite, chlorite and epidote in some rocks. The marginal fine-grained granites are texturally similar, except for a finer grain size. Accessory minerals in these rocks include brown primary biotite, clots of green secondary biotite and sphene. In places, the pluton is cut by veins of white granite in which the microperthite is completely albitized.

Well-formed albite crystals occur in the freshest granites that contain no epidote (e.g., 1779). Highly albitized rocks appear petrographically and geochemically quite distinct, and plagioclase in most early gabbros and associated hybrid rocks is not albitized. Thus, much of the albite in the North River granite appears primary.

\section{Gabbro and diabase}

The marginal gabbro bodies are medium-grained and subophitic. The primary mafic mineral is clinopyroxene, which has been replaced to varying extents by dusty amphibole or finegrained clots of chlorite, amphibole and secondary biotite. Some samples contain anhedral brown biotite with oriented rutile

Table 1. Mafic rocks from the North River pluton showing relationship of fractionation (indicated by increasing $\mathrm{TiO}_{2}$ content) to inferred sequence of emplacement and $\mathrm{Rb} / \mathrm{K}$ ratio.

\begin{tabular}{|c|c|c|c|c|}
\hline Sample & Structural setting & Relative age & $\% \mathrm{TiO}_{2}$ & $\mathrm{Rb} / \mathrm{K}_{2} \mathrm{O}$ \\
\hline 1641 & marginal gabbro & early & 1.49 & low \\
\hline 1672 & marginal gabbro & ?early & 1.51 & low \\
\hline 4462 & foliated sill & intermediate & 1.75 & high \\
\hline 4838 & cleaved dyke & intermediate & 1.78 & low \\
\hline 4831 & highly fractured sill & intermediate & 1.79 & high \\
\hline 4463 & undeformed gabbro dyke & late & 1.94 & high \\
\hline 2572 & undeformed gabbro dyke & late & 2.13 & high \\
\hline 4823 & sill cut by shear zone & intermediate & 2.52 & low \\
\hline 4832 & dyke cutting 4831 & late & 2.68 & high \\
\hline 4137 & marginal gabbro & $?$ & 2.69 & low \\
\hline 4467 & undeformed gabbro sill & late & 2.75 & high \\
\hline 1778 & undeformed diabase dyke & late & 2.90 & high \\
\hline 4827 & diabase dyke, locally cleaved & intermediate & 2.96 & low \\
\hline 1643 & undeformed composite dyke & late & 3.23 & high \\
\hline 2569 & undeformed diabase dyke & late & 3.60 & low \\
\hline 1772 & undeformed diabase dyke & late & 3.74 & high \\
\hline
\end{tabular}

Samples ordered by increasing $\mathrm{TiO}_{2}$ content. 
Table 2. Modal compositions of representative samples from the North River pluton.

\begin{tabular}{lrrrrrrrrr}
\hline Sample No. & 1641 & 1672 & 1666 & 1673 & 2388 & 2406 & 1642 & 1674 & 1675 \\
\hline Quartz & - & 0.3 & 44.1 & 27.0 & 17.9 & 6.6 & 17.9 & 19.3 & 37.6 \\
K-feldspar $^{1}$ & - & - & - & 34.0 & 30.0 & 54.9 & 29.6 & 52.3 & 30.4 \\
Albite in perthite $^{2}$ & - & - & - & - & 2.9 & - & 18.1 & 18.1 & 24.1 \\
Plagioclase $^{2}$ & 36.8 & 28.8 & 51.1 & 14.0 & 29.3 & 13.5 & 27.2 & 4.6 & 13.6 \\
Amphibole $_{\text {Biotite }}^{3}$ & 29.2 & 49.2 & - & - & - & - & - & - & - \\
Opaques $^{\text {Others }}$ & 14.7 & 10.6 & - & 20.0 & 17.6 & 22.2 & 4.6 & 1.6 & 1.6 \\
Veins & 0.9 & 2.1 & 1.7 & - & 1.8 & 0.3 & 2.0 & 3.9 & 2.7 \\
Total & 11.4 & 10.0 & 3.1 & 5.0 & 0.5 & 2.4 & 0.6 & - & - \\
& 6.7 & - & - & - & - & - & - & - & - \\
Colour Index & 99.9 & 100.0 & 100.0 & 100.0 & 100.0 & 100.0 & 100.0 & 100.0 & 100.0 \\
IUGS Name & 63.2 & 71.9 & 4.8 & 25 & 19.4 & 22.5 & 7.2 & 5.5 & 4.3 \\
& GA & GA & GR & GR & GR & QSY & QSY & GR & GR \\
\hline
\end{tabular}

1: includes K-feldspar in perthite

2: in granite, plagioclase appears to be all albite

3: includes secondary biotite

4: includes: chlorite, muscovite, sericite, epidote, calcite and dusty alteration minerals

GA - gabbro, GR - granite, QSY - quartz syenite, hybr - hybrid

Analysis based on counting of 100 to 1500 points in thin sections (depending on grain size of rock), stained following method of Bailey and Stevens (1960) with amaranth red used to stain plagioclase.

inclusions. Fine-grained opaque minerals are dispersed throughout the rock. Plagioclase shows alteration to sericite. The finegrained gabbro/diabase dykes and sheets are similar to the marginal gabbros, but are finer grained and lack brown biotite. Some samples contain large diamond-shaped clusters of chlorite/ serpentine that may be pseudomorphs after olivine.

\section{Intermediate hybrid rocks}

Most rocks of intermediate composition are texturally and mineralogically inhomogeneous at hand specimen and thin section scale. They occur at the margins of gabbro bodies and in some dykes and sills. The presence of mafic clots, wisps and stringers in the granitic hybrid rocks, and granitic stringers, lenses and large subhedral K-feldspar phenocrysts in the more mafic hybrid rocks, are consistent with the mingling of two penecontemporaneous magmas. The occurrence of geochemically analagous felsic and mafic lavas interbedded in the Fountain Lake Group is consistent with this interpretation.

Five textural types are distinguished: (1) partly assimilated granitic lenses and stringers in a finer mafic matrix; (2) a mafic matrix containing isolated quartz or K-feldspar phenocrysts; in some rocks the K-feldspar is rimmed by plagioclase. This is inferred to represent further assimilation than type (1); (3) irregularclots and contorted wisps of mafic material surrounding subhedral feldspar phenocrysts that show little alteration and disintegration; (4) mafic xenoliths set in a matrix of generally mafic or intermediate composition. Some such xenoliths have corroded margins; in others the margin is fine-grained, apparently chilled; (5) in some intermediate dykes, large areas that appear homogeneous, with evidence of hybrid character occurring only locally. These represent the most complete mixing of mafic and felsic magma.

The principal minerals in the hybrid rocks are plagioclase, K-feldspar, quartz, amphibole, green and brown biotite and opaque oxides (Table 2). The alteration minerals also include chlorite and epidote. In some hybrid rocks plagioclase has rims or patches of perthite.

\section{Deformation and secondary alteration}

Particularly near the southern margin of the North River pluton, many of the rocks show deformation features, accompanied by alteration of ferromagnesian minerals and feldspars. Groundmass quartz has recrystallised; some feldspars are fractured; clinopyroxene has been altered to amphibole. Cleavage in some mafic rocks is defined by fibrous actinolite, dusty opaque minerals and in some cases chlorite.

Many of the rocks contain fine-grained green secondary biotite, concentrated in fractures and veins. Studies in nearby plutons show that this biotite can be distinguished from primary biotite by its colour and mode of occurrence; it also has a different chemical composition (Pe-Piper and Turner, 1988). In the granites, it is associated with small amounts of chlorite, muscovite 
and epidote. In some microgranite dykes, secondary biotite is the main ferromagnesian mineral in megascopic mafic stringers and clots. These textural relationships suggest that the biotite resulted from a late hydrothermal event entering fractured rocks. Similar alteration has been recognised in other granites along the Cobequid Fault zone (Pe-Piper and Tumer, 1988; Waldron et al., 1989; Pe-Piper et al., in press).

\section{GEOCHEMISTRY}

\section{Introduction}

Representative chemical analyses for the rocks of the North River pluton are given in Tables 3 to 6 . The analytical methods used for these data are described in Pe-Piper and Piper (1989). The North River pluton includes rocks ranging from gabbro to granite, with silica content ranging from 43 to $78 \mathrm{wt}$. \%. On Harker diagrams (Fig. 3) the mafic rocks $\left(45-50 \% \mathrm{SiO}_{2}\right)$ show a variability in many elements that does not correlate with $\mathrm{SiO}_{2}$ content. The hybrid and granitic rocks exhibit somewhat less scattered and non-linear distribution patterns of $\mathrm{TiO}_{2}, \mathrm{MgO}$, $\mathrm{CaO}, \mathrm{Fe}_{2} \mathrm{O}_{3}, \mathrm{P}_{2} \mathrm{O}_{5}$ and $\mathrm{MnO}$ against $\mathrm{SiO}_{2}$. The $\mathrm{Al}_{2} \mathrm{O}_{3}$ shows a convex upward distribution. $\mathrm{Na}_{2} \mathrm{O}$ and $\mathrm{K}_{2} \mathrm{O}$ show substantial scatter. The scatter may be the product of potassium metasomatism reflected in the variable abundance of secondary biotite. The trends for the trace elements (Fig. 4) show more scatter. In the mafic rocks, $\mathrm{Nb}$ covaries with $\mathrm{TiO}_{2}$. Overall, $\mathrm{Sr}$ shows a negative correlation with $\mathrm{SiO}_{2}$. Most hybrid rocks and the granitoid rocks have low loss-on-ignition (L.O.I.) whereas the mafic rocks have a much higher L.O.I.

\section{Granitoid rocks}

The granitoid rocks of the North River pluton are geochemically similar to those previously described from other plutons in the western Cobequid Highlands, particularly the West Moose River pluton (Pe-Piper et al., in press). The alteration of the North River pluton means that indicators such as LILE abundance may be unreliable, but the high $\mathrm{SiO}_{2}$ and alkalies $\left(\mathrm{Na}_{2} \mathrm{O}+\mathrm{K}_{2} \mathrm{O}\right)$, very high $\mathrm{Ga}$ and low $\mathrm{Al}_{2} \mathrm{O}_{3}$, and high $\mathrm{Zr}, \mathrm{Y}$, and $\mathrm{Nb}$ appear diagnostic of sub-alkalic A-type granite. Whalen et al. (1987) indicated that high $\mathrm{Ga} / \mathrm{Al}$ (Fig. 5) is a useful criterion for distinguishing A-type granites from fractionated I-type granites (e.g., Tuach et al., 1986).

In detail, the North River pluton differs from the West Moose River pluton in showing less alkalic character in some trace elements. Average $\mathrm{Ga} / \mathrm{Al}$ is $2.7 \times 10^{4}$ (West Moose River pluton $3.3 \times 10^{4}$ ); average $\mathrm{Zr}+\mathrm{Nb}+\mathrm{Y}+\mathrm{Ce}$ is 375 (West Moose River pluton 444). The Hanna Farm pluton is similar to the North River pluton, whereas the Cape Chignecto and Hart Lake - Byers Lake plutons appear to have more alkalic character. The North River pluton is thus one of the least alkalic of the Cobequid Highland Devonian-Carboniferous plutons that show a continuum of compositions in granites that are mineralogically and geochemically clearly of A-type.

\section{Mafic intrusive rocks}

The mafic intrusive rocks are chemically similar to those described by Pe-Piper et al. (in press) from the West Moose River pluton. The less fractionated mafic rocks in their general composition resemble olivine-normative continental tholeiites; more fractionated varieties resemble alkali basalts. They have high normative olivine content and variable normative hypersthene (Table 4). On a $\mathrm{Zr} / \mathrm{P}_{2} \mathrm{O}_{5}$ versus $\mathrm{TiO}_{2}$ diagram (Floyd and Winchester, 1975), all the rocks plot in the alkalic field except the low-Ti early marginal gabbros which are subalkaline. On a $\mathrm{SiO}_{2}$ versus $\mathrm{Zr} / \mathrm{TiO}_{2}$ plot (after Winchester and Floyd, 1977), however, all but one alkali basalt dyke plot in the subalkaline basalt field. $\mathrm{Zr} / \mathrm{Y}$ ratios indicate a within-plate tectonic setting (Pearce and Norry, 1979).

Most of the mafic rocks show substantial evidence of alteration. Loss on ignition is high, typically 1.5 to $2.5 \%$. Plots of $\mathrm{K}_{2} \mathrm{O}$, $\mathrm{Na}_{2} \mathrm{O}$ and $\mathrm{CaO}$ show substantial scatter against $[\mathrm{Mg}$ ] (magnesium number, defined in footnote to Table 4). Pe-Piper et al. (in press) demonstrated that less mobile elements consistently show less scatter when plotted against $\mathrm{TiO}_{2}$ than they do plotted against $[\mathrm{Mg}]$ or $\mathrm{MgO}$, and that $\mathrm{TiO}_{2}$ can be used as an indicator of the degree of fractionation. Plots of elements against $\mathrm{TiO}_{2}$ (Fig. 6) show considerable scatter for the LILE and $\mathrm{Nb}$, but reasonably strong correlation for $\mathrm{P}_{2} \mathrm{O}_{5}, \mathrm{Fe}_{2} \mathrm{O}_{3}, \mathrm{Zr}$, and $\mathrm{Ga} / \mathrm{Al}$.

\section{Fractionation and relative age}

Using $\mathrm{TiO}_{2}$ as an index of fractionation, the least fractionated rocks are the marginal gabbros in North and Bass rivers, with $\mathrm{TiO}_{2}<1.6 \%$ (Table 1). These appear to be the earliest mafic rocks, approximately synchronous with granite intrusion. In contrast, most samples from the main dyke swarm cutting the pluton and country rocks are highly fractionated, with $\mathrm{TiO}_{2}>2.7 \%$. Rocks showing an intermediate degree of fractionation correspond in general to mafic bodies that cut the granite but have been deformed with it, and are thus interpreted to be of intermediate age (Table 1). Thus the mafic rocks inferred to be later on the basis of structural evidence are chemically more fractionated.

\section{Alteration}

The alteration of the mafic rocks discussed above does not appear to be associated with discrete fractures. Neither does it appear to influence the adjacent granites (see analysis 4824, Table 3, from the margin of a sill). The mafic rocks might be altered either by magmatic fluids that accompanied their intrusion, as proposed by Whalen and Currie (1984) for the Topsails complex, or through hydrothermal circulation driven by the hot mafic bodies of residual fluids in the cooling granite. Pe-Piper $e t$ al. (in press) argued for the West Moose River pluton that the latter hypothesis was more likely, because of evidence for the abundance of halogens, such as the high $\mathrm{Ga} / \mathrm{Al}$ ratio and high $\mathrm{F}$ and $\mathrm{Cl}$ in secondary biotite.

Alteration has also resulted in unusually high $\mathrm{Rb} / \mathrm{K}$ and 
Table 3. Chemical analyses of representative hybrid and granitoid rocks.

\begin{tabular}{|c|c|c|c|c|c|c|c|c|c|c|c|c|}
\hline Sample No. & 4829 & 1640 & 2388 & 1673 & 1642 & 1674 & 2406 & 1779 & 1675 & 4824 & 1666 & 1639 \\
\hline \multicolumn{13}{|c|}{ Major elements (wt. \%) } \\
\hline $\mathrm{SiO}_{2}$ & 56.27 & 59.08 & 66.40 & 66.50 & 70.32 & 72.80 & 73.82 & 74.92 & 75.50 & 75.85 & 77.60 & 74.50 \\
\hline $\mathrm{TiO}_{2}$ & 1.34 & 1.69 & 0.74 & 0.75 & 0.42 & 0.35 & 0.25 & 0.19 & 0.22 & 0.15 & 0.12 & 0.30 \\
\hline $\mathrm{l}_{2} \mathrm{O}_{3}$ & 15.58 & 15.67 & 14.49 & 14.50 & 15.42 & 13.90 & 13.26 & 12.81 & 12.70 & 12.51 & 12.34 & 12.60 \\
\hline $\mathrm{e}_{2} \mathrm{O}_{3 \mathrm{t}}$ & & 7. & 4 & 4.55 & 2.42 & 2.12 & 1.70 & 1.97 & 1.70 & 47 & 0.61 & 2.57 \\
\hline Ino & 0 & & & 0 & & 0. & & & & & & 0.02 \\
\hline $\lg$ & 5 & & 1.8 & 1.5 & 0.46 & 0.3 & 0.71 & 0.1 & 0.2 & 0.4 & 0.41 & 0.82 \\
\hline 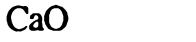 & 4 & 4.57 & 2.6 & 2. & 0. & 0. & 0. & 0. & & 0. & 0.8 & 0.60 \\
\hline $\mathrm{Na}_{2} \mathrm{O}$ & & 4.00 & 3.28 & 3.97 & 4.78 & 4.14 & 2.90 & 3.59 & 3.70 & 3.59 & 6.91 & 4.95 \\
\hline $\mathrm{K}_{2} \mathrm{O}$ & 3.35 & 3.11 & 3.88 & 4.30 & 5.41 & 5.32 & 5.51 & 5.45 & 5.26 & 5.43 & 0.12 & 3.00 \\
\hline $\mathrm{P}_{2} \mathrm{O}_{5}$ & 0.16 & 0.48 & 0.12 & 0.13 & 0.07 & 0.05 & 0.04 & 0.02 & 0.04 & 0.01 & 0.02 & 0.04 \\
\hline L.O.I. & 1.40 & 0.62 & 0.90 & 0.85 & 0.54 & 0.62 & 0.20 & 0.31 & 0.54 & 0.40 & 0.60 & 0.85 \\
\hline Total & 99.78 & 99.59 & 98.94 & 99.50 & 100.17 & 100.22 & 99.00 & 99.62 & 100.31 & 100.09 & 99.58 & 100.25 \\
\hline
\end{tabular}

Trace elements (ppm)

\begin{tabular}{lrrrrrrrrrrrr}
$\mathrm{Ba}$ & 231 & 637 & 427 & 488 & 724 & 518 & 483 & 331 & 360 & 390 & 32 & 253 \\
$\mathrm{Rb}$ & 279 & 122 & 155 & 168 & 125 & 205 & 211 & 189 & 198 & 145 & - & 56 \\
$\mathrm{Sr}$ & 208 & 230 & 136 & 116 & 53 & 51 & 57 & 30 & 30 & 48 & 45 & 67 \\
$\mathrm{Y}$ & 47 & 54 & 45 & 43 & 41 & 40 & 51 & 73 & 36 & 56 & 35 & 63 \\
$\mathrm{Zr}$ & 206 & 378 & 327 & 316 & 370 & 303 & 239 & 189 & 188 & 169 & 293 & 375 \\
$\mathrm{Nb}$ & 10 & 23 & 23 & 21 & 19 & 23 & 25 & 33 & 27 & 32 & 47 & 40 \\
$\mathrm{Th}$ & - & 13 & 24 & 19 & 25 & 31 & 27 & 26 & 26 & - & 10 & 22 \\
$\mathrm{~Pb}$ & - & 18 & 23 & 19 & 16 & 22 & 31 & 19 & 19 & - & 5 & 12 \\
$\mathrm{Ga}$ & 22 & 21 & 25 & 20 & 19 & 18 & 22 & 18 & 18 & 16 & 19 & 17 \\
$\mathrm{Zn}$ & 69 & 83 & 29 & 14 & 18 & 14 & 34 & 18 & 16 & 14 & 14 & 16 \\
$\mathrm{Cu}$ & 13 & 14 & 7 & 11 & 1 & 12 & 1 & - & 7 & 25 & - & 10 \\
$\mathrm{Ni}$ & 54 & 20 & 31 & 22 & 13 & 15 & 36 & 18 & 17 & - & 11 & 17 \\
$\mathrm{~V}$ & 176 & 118 & 76 & 72 & 15 & 9 & 6 & 4 & 7 & 5 & 2 & 28 \\
$\mathrm{Cr}$ & 83 & 26 & 28 & 43 & 19 & 29 & 1 & 27 & 39 & 10 & 7 & 59 \\
\hline
\end{tabular}

- indicates not detected

4829: Subhorizontal mafic sheet, uncleaved, cutting fractured granite, near southern margin of pluton, Bass River; 1640: Quartz monzodiorite with granitic texture which contains plagioclase, quartz, K-feldspar, amphibole, secondary biotite, chlorite, epidote and opaques; 2388: Inhomogeneous hybrid rock (granite) with granitic and granophyric texture which contains plagioclase, quartz, K-feldspar, biotite, opaques, homblende, secondary biotite, calcite, epidote and sphene; 1673: Medium-grained granophyric granite, contains plagioclase, quartz, K-feldspar, opaque oxides, secondary biotite, sericite and minor epidote; 1642: Medium- to coarse-grained granite containing plagioclase (albite), orthoclase, quartz and opaques; 1674: Fine-grained granophyric granite consisting of plagioclase (albite), quartz, K-feldspar, opaques, secondary biotite, sericite and rare epidote; 2406: Porphyritic granite with hybrid texture, contains euhedral phenocrysts of plagioclase (albite), perthite and quartz in cryptocrystalline groundmass; 1779: Coarse-grained granophyric granite consisting of Kfeldspar, quartz, plagioclase (albite), opaques and chlorite; 1675: coarse-grained graphic granite containing plagioclase (albite), quartz, K-feldspar, opaques, secondary biotite, sericite and epidote; 4824: coarse granite immediately above sill of 4823 (Table 4). Other elements analysed: $\mathrm{La}=71.14, \mathrm{Ce}=137, \mathrm{Nd}=69.72, \mathrm{Sm}=13.06, \mathrm{Eu}=0.84, \mathrm{~Tb}=2.11, \mathrm{Yb}=6.63, \mathrm{Lu}=0.89$. $\mathrm{Cs}=0.46, \mathrm{Hf}=6.96, \mathrm{Ta}=2.93, \mathrm{Th}=22.49, \mathrm{U}=3.56 ; 1666$ : Coarse-grained sliver white granite in Cobequid Fault zone consisting of albite and quartz with minor opaques. K-feldspar is absent, possibly albitized. Relationship to North River pluton uncertain; 1639: porphyritic microgranite from a composite dyke, contains anhedral phenocrysts of plagioclase (albite), orthoclase (or microperthite) and quartz in a slightly altered groundmass.

$\mathrm{Cs} / \mathrm{K}$ ratios, which are presumably associated with the growth of secondary minerals, including biotite. A plot of $\mathrm{Rb} / \mathrm{K}$ against $\mathrm{Ga} /$ $\mathrm{Al}$ shows two trends or assemblages (Fig. 7). The assignment of rocks to these two assemblages (Table 1) follows geographic distribution and to a lesser extent, relative age, suggesting that the alteration is systematic, not random. The rocks with high Rb/K all occur in a broad zone extending from the northern part of North River to East River, with the exception of one late dyke at the southern margin of the pluton in North River; they include some substantially deformed (earlier) intrusions. Airborne radiometric maps show evidence for a $\mathrm{K}$ anomaly in this area. Although neither $\mathrm{Rb}$ nor $\mathrm{Rb} / \mathrm{K}$ show significant variation with $\mathrm{TiO}_{2}$, the 
Table 4. Chemical analyses of representative mafic rocks.

\begin{tabular}{|c|c|c|c|c|c|c|c|c|c|c|c|c|c|c|c|c|}
\hline Sample No. & 2569 & 4137 & 1772 & 4462 & 1778 & 1641 & 4832 & 4823 & 4467 & $1643^{1}$ & 4827 & 4463 & 2572 & 4838 & 4831 & 1672 \\
\hline \multicolumn{17}{|c|}{ Major elements (wt. \%) } \\
\hline $\mathrm{SiO}_{2}$ & 44.27 & 44.60 & 44.85 & 44.85 & 44.86 & 45.00 & 45.13 & 45.14 & 45.45 & 45.52 & 45.63 & 45.74 & 46.35 & 46.76 & 46.79 & 48.60 \\
\hline $\mathrm{TiO}_{2}$ & 3.60 & 2.69 & 3.74 & 1.75 & 2.90 & 1.49 & 2.68 & 2.52 & 2.75 & 3.23 & 2.96 & 1.94 & 2.13 & 1.78 & 1.79 & 1.51 \\
\hline $\mathrm{Al}_{2} \mathrm{O}_{3}$ & 14.10 & 14.62 & 13.43 & 13.77 & 14.54 & 17.25 & 15.24 & 15.50 & 14.99 & 14.15 & 14.89 & 15.17 & 14.92 & 16.75 & 16.05 & 16.10 \\
\hline $\mathrm{Fe}_{2} \mathrm{O}_{3 t}$ & 15.71 & 14.53 & 14.97 & 12.69 & 14.42 & 12.16 & 13.55 & 13.76 & 12.82 & 16.30 & 14.44 & 12.41 & 13.11 & 12.17 & 10.66 & 11.10 \\
\hline $\mathrm{MnO}$ & 0.28 & 0.22 & 0.26 & 0.19 & 0.21 & 0.12 & 0.36 & 0.39 & 0.26 & 0.21 & 0.40 & 0.17 & 0.14 & 0.22 & 0.25 & 0.10 \\
\hline $\mathrm{MgO}$ & 5.77 & 7.07 & 6.28 & 10.50 & 6.85 & 8.20 & 6.54 & 7.13 & 6.51 & 6.58 & 6.31 & 8.42 & 7.40 & 6.38 & 77 & 6.88 \\
\hline $\mathrm{CaO}$ & 9.28 & 9.65 & 9.81 & 8.17 & 9.07 & 6.80 & 9.74 & 8.60 & 9.28 & 9.82 & 9.34 & 9.03 & 8.30 & 10.18 & 9.80 & 8.67 \\
\hline $\mathrm{Na}_{2} \mathrm{O}$ & 2.50 & 2.58 & 2.10 & 1.24 & 1.50 & 1.86 & 2.07 & 1.91 & 2.81 & 2.33 & 1.74 & 1.80 & 2.37 & 1.92 & 2.28 & 2.4 \\
\hline $\mathrm{K}_{2} \mathrm{O}$ & 1.63 & 0.57 & 1.25 & 2.38 & 1.41 & 2.73 & 0.78 & 1.32 & 0.89 & 1.61 & 0.92 & 0.75 & 1.88 & 0.92 & 1.41 & 2.3 \\
\hline $\mathrm{P}_{2} \mathrm{O}_{5}$ & 0.73 & 0.32 & 0.67 & 0.33 & 0.59 & 0.15 & 0.60 & 0.33 & 0.75 & 1.79 & 0.36 & 0.39 & 0.30 & 0.13 & 0.13 & 0.19 \\
\hline L.O.I. & 1.90 & 2.30 & 1.80 & 2.80 & 1.90 & 3.38 & 2.90 & 3.10 & 2.30 & - & 2.70 & 3.50 & 2.90 & 2.20 & 2.50 & 1.77 \\
\hline Total & 99.77 & 99.15 & 99.16 & 98.67 & 98.25 & 99.14 & 99.59 & 99.70 & 98.81 & 101.54 & 99.69 & 99.32 & 99.80 & 99.41 & 99.43 & 99.75 \\
\hline \multicolumn{17}{|c|}{ Trace elements (ppm) } \\
\hline $\mathrm{Ba}$ & 285 & 203 & 279 & 64 & 270 & 252 & 285 & 309 & 376 & 286 & 241 & 122 & 200 & 533 & 297 & 225 \\
\hline$R b$ & 77 & 27 & 73 & 256 & 87 & 167 & 55 & 72 & 59 & 129 & 43 & 56 & & 52 & & 117 \\
\hline Sr & 314 & 262 & 290 & 146 & 293 & 166 & 290 & 258 & 376 & 237 & 277 & 183 & 255 & 247 & 207 & 293 \\
\hline Y & 47 & 36 & 45 & 32 & 42 & 28 & 37 & 33 & 39 & 74 & 32 & 39 & 30 & 29 & 33 & 24 \\
\hline $\mathbf{Z r}$ & 284 & 163 & 277 & 131 & 242 & 97 & 233 & 158 & 231 & 404 & 200 & 190 & 164 & 94 & 94 & 111 \\
\hline$\overline{N b}$ & 22 & 11 & 20 & 9 & 18 & 8 & 16 & 7 & 17 & 27 & 9 & 12 & 12 & - & - & 10 \\
\hline Th & - & 13 & - & - & - & - & - & - & - & 2 & - & - & - & - & - & 1 \\
\hline $\mathrm{Pb}$ & 8 & 4 & 8 & - & 4 & 7 & - & - & - & 11 & - & - & 1 & - & . & 15 \\
\hline $\mathrm{Ga}$ & 27 & 27 & 31 & 18 & 32 & 20 & 25 & 20 & 27 & 23 & 20 & 19 & 25 & 15 & 20 & 19 \\
\hline $\mathrm{Zn}$ & 82 & 136 & 100 & 103 & 69 & 76 & 137 & 101 & 211 & 124 & 139 & 90 & 62 & 178 & 136 & 44 \\
\hline $\mathrm{Cu}$ & 53 & 67 & 55 & 40 & 47 & 50 & 59 & 62 & 49 & 27 & 57 & 20 & 40 & 108 & 74 & 34 \\
\hline $\mathrm{Ni}$ & 53 & 11 & 47 & 355 & 58 & 117 & 100 & 92 & 110 & 58 & 85 & 174 & 75 & 173 & 163 & 69 \\
\hline V & 359 & 378 & 375 & 248 & 284 & 264 & 263 & 275 & 277 & 194 & 311 & 253 & 280 & 257 & 231 & 236 \\
\hline $\mathrm{Cr}$ & 55 & 129 & 74 & 415 & 65 & 282 & 82 & 97 & 111 & 77 & 73 & 314 & 187 & 174 & 152 & 160 \\
\hline
\end{tabular}

$[\mathrm{Mg}]^{*}$

$\begin{array}{llll}0.46 & 0.53 & 0.49 & 0.66\end{array}$

$0.53 \quad 0.61$

$\begin{array}{lll}0.53 & 0.55 & 0.54\end{array}$

$0.48 \quad 0.50$

$\begin{array}{llll}0.61 & 0.57 & 0.55 & 0.63\end{array}$

0.59

Normative*

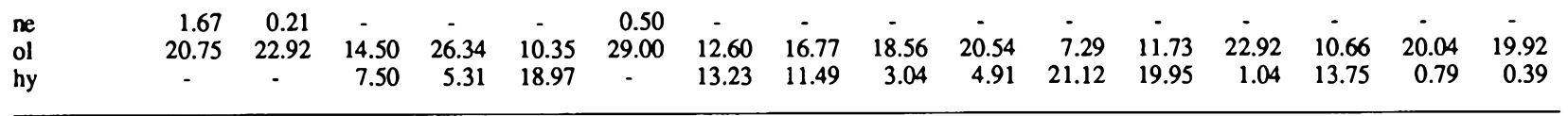

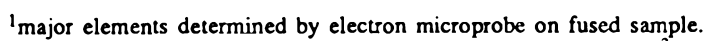

* $[\mathrm{Mg}]$ number and normative calculations based on adjusting $\mathrm{Fe}^{3+} /$ total $\mathrm{Fe}$ to 0.15

- indicates not detected; n.d. not determined.

2569: North-trending gabbro dyke, Gundalow Brook, with plagioclase, homblende, pyroxene, chlorite, opaques, epidote and apatite; 4137: marginal gabbro, westem margin of pluton; 1772, 1778: Diabase dykes, upper North River, cutting the granite. 1778 trends $015^{\circ}$. Sub-ophitic texture containing plagioclase, clinopyroxene, amphibole, opaques, chlorite, secondary biotite and apatite; 4462: Diabase sheet, East River, highly deformed, with fibrous groundmass consisting of chlorite, opaque oxides, antigorite, actinolite and epidote. Large diamond-shaped pseudomorphs of actinolite, antigorite and epidote common. Rare small fragments of feldspar crystals in groundmass; 1641: marginal gabbro body. Eaton Brook. North River, that is cut by granitic veins. Subophitic texture with amphibole, biotite, opaques and hematite; 4832: dyke with chilled margin cutting gabbro sill 483!, northwestern part of pluton. Subophitic texture, plagioclase, opaque oxides, actinolite, chlorite, epidote, and secondary biotite; 4823: Diabase sub-horizontal sheet, cutting granite, upper Bass River. Ophitic to subophitic, pseudomorphs of actinolite, plagioclase and opaque oxide phenocrysts. Relicts of pinkish augite. Groundmass includes chlorite, epidote and secondary biotite; 4467: Gabbroic sub-horizontal sheet, East River, cutting granite in the northem part of the pluton. Medium-grained, sub-ophitic texture, with plagioclase, brown biotite, acicular apatite inclusions. Clinopyroxene altered to fibrous actinolite and fibrolamellar antigorite with few relict pyroxene cores. Fractures filled with secondary biotite, chlorite and epidote; 1643: Diabase from a composite dyke (diabase+microgranite) cutting granite (?and marginal gabbro body). Eaton Brook, North River. Subophitic texture containing plagioclase, amphibole, opaques, secondary biotite, chlorite and epidote; 4827: diabase dyke, cuts granite, strike $150^{\circ}$, minor cleavage, lower Bass River; 4463: Coarse-grained diabase dyke (cuts fractures in the granite), East River (strike 175 ${ }^{\circ}$ ). predominantly epidote, chlorite and clay minerals defining a foliation. Broken altered amphibole and plagioclase crystals. Patches of coarsely crystalline epidote. Some rounded or elliptical clots contain chlorite, intergrown with secondary biotite and rimmed with epidote; $2572:$ Gabbro dyke trending $100^{\circ}$. Bass River, (cuts the granite) with sub-ophitic texture containing plagioclase, amphibole, pyroxene, chlorite, opaques and epidote; 4838: irregular diabase dyke, minor cleavage, cuts granite, upper North River. Subophitic with plagioclase and pinkish augite, altered to actinolite, sericite, chlorite and dusty opaques; 4831 : Subhorizontal gabbro sheet (which is cut by dyke 4832), northeastern part of pluton. Subophitic with plagioclase and pinkish augite, altered to actinolite, sericite, chlorite and dusty opaques; 1672: Marginal gabbro body (with unclear field relationships to granite), southem Bass River, with sub-ophitic texture containing plagioclase, pyroxene, opaques and chlorite.

rocks with high $\mathrm{Rb} / \mathrm{K}$ ratio show greater enrichment in $\mathrm{P}$ and $\mathrm{Zr}$ relative to $\mathrm{TiO}_{2}$ (Fig. 6a, b).

\section{Intermediate (hybrid) rocks}

The intermediate rocks of hybrid composition display a wide range of chemical composition. Mixing calculations have been made to examine the hypothesis that the analysed hybrid rocks can be obtained by mixing observed mafic and granitic compo- sitions. These calculations show that large residuals are obtained if the early marginal gabbros are used as the mafic component (even to produce the hybrid rocks adjacent to these gabbros). More reasonable residuals (sum of squares $<6 \%$ ) are obtained from mixing of granite with magma compositions represented by the dykes with greater enrichment in incompatible elements, and residuals can be further reduced by allowing minor fractionation of feldspar. 
Table 5. Chemical analyses of REE and selected trace elements from representative mafic rocks.

\begin{tabular}{lrrrr}
\hline Sample No. & 4462 & 4467 & 1643 & 4463 \\
\hline & & & & \\
$\mathrm{La}$ & 13.70 & 27.30 & 45.50 & 25.80 \\
$\mathrm{Ce}$ & 31.00 & 60.00 & 82.00 & 39.00 \\
$\mathrm{Nd}$ & 17.00 & 31.00 & 36.00 & 24.00 \\
$\mathrm{Sm}$ & 4.38 & 7.23 & 9.85 & 6.19 \\
$\mathrm{Eu}$ & 1.28 & 2.61 & 3.25 & 1.50 \\
$\mathrm{~Tb}$ & 1.00 & 1.30 & 1.70 & 1.20 \\
$\mathrm{Yb}$ & 2.77 & 3.57 & 5.06 & 3.72 \\
$\mathrm{Lu}$ & 0.42 & 0.53 & 0.73 & 0.58 \\
$\mathrm{Cs}$ & 11.70 & 4.60 & 7.60 & 3.30 \\
$\mathrm{Hf}$ & 3.50 & 5.50 & 8.60 & 4.50 \\
$\mathrm{Sb}$ & 0.50 & 0.40 & 0.30 & 0.70 \\
$\mathrm{Sc}$ & 36.50 & 35.20 & 41.50 & 43.60 \\
$\mathrm{Ta}$ & 0.50 & 1.00 & 1.00 & 0.50 \\
$\mathrm{Th}$ & 0.40 & 0.80 & 1.30 & 0.50 \\
$\mathrm{U}$ & 0.50 & 0.40 & 0.40 & 0.30 \\
& & & & \\
\hline
\end{tabular}

Major elements presented in Table 4

\section{Structural level of the North River pluton}

The North River pluton differs from the West Moose River pluton in having steep straight margins and a lack of roof pendants. It differs from the West Moose River, Pleasant Hills and Cape Chignecto plutons in lacking subvolcanic lithologies within the pluton. These observations suggests that it may represent a deeper structural level than some of the plutons of the Western Cobequid Highlands, particularly the West Moose River pluton. This may account for the greater enrichment in $\mathrm{Ga} / \mathrm{Al}$ in the West Moose River pluton, since $F$ which enhances $\mathrm{Ga}$ by complexing tends to concentrate in the upper parts of magma chambers (Hildreth, 1981). It may also account for the greater number of hybrid rocks in the North River pluton than in the West Moose River and Pleasant Hills plutons.

\section{THE ROLE OF TECTONIC SETTING}

Many granites emplaced in shear zones show magmatic flow structures (Guineberteau et al., 1987) and deformation that took place before full crystallisation of the pluton (Hutton, 1988a). In addition, continued motion on the shear zone may result in postintrusion deformation. Such shear-zone granites have been interpreted as filling crustal openings created by pull-apart during shearing, and the shear zone faults have been regarded as providing pathways for pre-existing granitic magmas to reach the surface (Guineberteau et al., 1987; Hutton, 1988b).

Most well known shear zone granites occur in areas where granitic magmas appear to have been generated either by continental collision (e.g., Davies, 1982; Castro, 1985; Guineberteau et al., 1987) or by subduction (e.g., Hutton, 1982, 1988b). In these settings, the role of the shear zone is interpreted as being primarily a conduit, although Nicolas et al. (1977) and Strong and
Table 6. Chemical analyses of dyke rocks immediately west of the North River pluton.

\begin{tabular}{|c|c|c|c|c|c|c|c|}
\hline \multirow[b]{2}{*}{ Sample No. } & \multicolumn{5}{|c|}{ microgranite dykes } & \multicolumn{2}{|c|}{ mafic dykes } \\
\hline & 1089 & 395 & 857 & 873 & 856 & 4130 & 1627 \\
\hline \multicolumn{8}{|c|}{ Major elements (wt. \%) } \\
\hline $\mathrm{SiO}_{2}$ & 64.00 & 73.20 & 74.10 & 76.50 & 78.50 & 46.63 & 48.51 \\
\hline $\mathrm{TiO}_{2}$ & 1.01 & 0.23 & 0.20 & 0.17 & 0.20 & 1.39 & 3.44 \\
\hline $\mathrm{Al}_{2} \mathrm{O}_{3}$ & 15.90 & 13.10 & 12.60 & 12.20 & 10.90 & 16.27 & 14.08 \\
\hline $\mathrm{Fe}_{2} \mathrm{O}_{3}$ & 5.40 & 2.37 & 2.86 & 1.51 & 1.88 & 11.03 & 17.55 \\
\hline $\mathrm{MnO}$ & 0.03 & 0.03 & 0.04 & 0.02 & 0.02 & 0.22 & 0.02 \\
\hline $\mathrm{MgO}$ & 1.86 & 0.75 & 1.04 & 0.26 & 0.60 & 9.64 & 3.80 \\
\hline $\mathrm{CaO}$ & 1.80 & 0.65 & 0.29 & 0.21 & 0.70 & 10.11 & 3.18 \\
\hline $\mathrm{Na}_{2} \mathrm{O}$ & 6.65 & 4.09 & 4.61 & 3.99 & 4.24 & 1.79 & 3.26 \\
\hline $\mathrm{K}_{2} \mathrm{O}$ & 1.62 & 4.32 & 3.03 & 4.53 & 2.40 & 1.52 & 4.23 \\
\hline $\mathrm{P}_{2} \mathrm{O}_{5}$ & 0.25 & 0.03 & 0.03 & 0.02 & 0.04 & 0.14 & 0.89 \\
\hline L.O.I. & 1.31 & 0.93 & 1.00 & 0.77 & 0.77 & 2.20 & - \\
\hline Total & 99.83 & 99.70 & 99.80 & 100.18 & 100.25 & 100.94 & 98.96 \\
\hline \multicolumn{8}{|c|}{ Trace elements (ppm) } \\
\hline $\mathrm{Ba}$ & 214 & 498 & 479 & 383 & 341 & 210 & 309 \\
\hline$\overline{\mathrm{Rb}}$ & 78 & 86 & 47 & 86 & 38 & 77 & 349 \\
\hline Sr & 162 & 82 & 58 & 55 & 82 & 273 & 130 \\
\hline$Y$ & 48 & 64 & 49 & 30 & 56 & 27 & 57 \\
\hline$Z_{x}$ & 107 & 226 & 208 & 248 & 182 & 99 & 240 \\
\hline$\overline{\mathrm{Nb}}$ & 27 & 31 & 25 & 32 & 25 & 6 & 17 \\
\hline Th & 13 & 22 & 23 & 18 & 19 & - & 5 \\
\hline $\mathrm{Pb}$ & 9 & 8 & 8 & 13 & 9 & - & 11 \\
\hline $\mathrm{Ga}$ & 24 & 17 & 17 & 15 & 14 & 23 & 26 \\
\hline $\mathrm{Zn}$ & 26 & 18 & 21 & 13 & 19 & 130 & 26 \\
\hline $\mathrm{Cu}$ & 3 & - & - & 15 & - & 79 & 2 \\
\hline $\mathrm{Ni}$ & 7 & 9 & 10 & 6 & 7 & 111 & 47 \\
\hline V & 46 & 7 & 11 & 2 & 16 & 268 & 373 \\
\hline $\mathrm{Cr}$ & 5 & 6 & 1 & 5 & 8 & 95 & 10 \\
\hline
\end{tabular}

1089: Deformed hybrid rock (quartz monzodiorite), Lynn Road. Principally plagioclase, quartz and K-feldspar; also brown biotite, green (secondary) biotite, opaque oxides, chlorite and epidote; 395: deformed microgranite, Lynn Road, containing perthite, quartz and plagioclase phenocrysts in a sheared cryptocrystalline matrix. It also contains opaques, chlorite, epidote and zircon; 857, 856: sheared microgranites, Lynn Road, with phenocrysts of perthite, plagioclase, quartz in a cryptocrystalline groundmass which is locally sheared or granophyric. Also they contain opaques, chlorite, epidote and secondary biotite along fractures; 873: sheared microgranite, Lynn Road, containing phenocrysts of perthite, plagioclase and quartz in sheared cryptocrystalline groundmass and few opaques. Secondary biotite and $\mathrm{Fe}$ stain occur along fractures.

4130: dyke cutting Jeffers Group $200 \mathrm{~m}$ southwest of North River pluton. Plagioclase, actinolite, and dusty opaques; 1627: dyke in the "dyke complex" on North River, immediately south of the North River pluton. Plagioclase phenocrysts in an altered groundmass including secondary biotite. Opaque oxides abundant.

Hanmer (1981) suggest that strike-slip faulting may also play a role in frictional heating.

The granites of the Cobequid fault zone differ from these previously described examples in that their overall geochemistry suggests a "within-plate" petrogenesis, implying an extensional setting. Furthermore, the generally tholeiitic rather than alkalic character of the associated mafic rocks suggests that this extension was regional rather than local (Pe-Piper et al., in press). The granites do not appear to result from tapping of earlier Appalachian magmas; although the South Mountain Batholith (Clarke and Muecke, 1985) lies only $60 \mathrm{~km}$ to the south, it is geochemically quite different (e.g., rich in $\mathrm{U}$ and $\mathrm{Th}$ ).

Granitic plutonism along the Cobequid Fault is associated with large gabbro plutons, such as the Economy River and Folly 

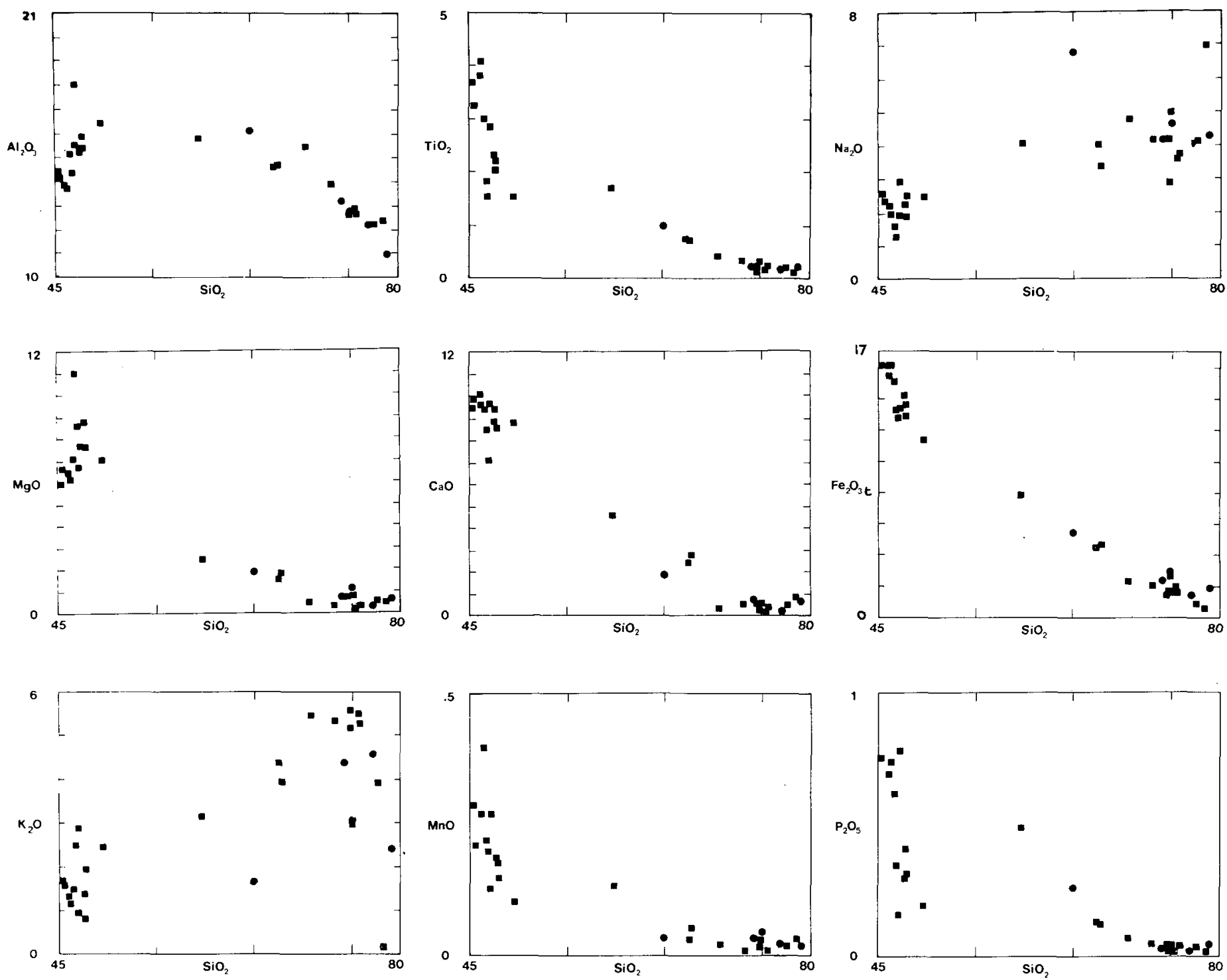

Fig. 3. Major element oxides plotted against $\mathrm{SiO}_{2}$ for rocks of the the North River pluton and adjacent hypabyssal rocks. Solid squares - North River pluton rocks; solid circles - hypabyssal rocks from the western margin of the pluton. Samples with between $55 \%$ and $70 \% \mathrm{SiO}_{2}$ are from rocks with hybrid texture. Analyses recalculated on a volatile-free basis.

Lake plutons (Donohoe and Wallace, 1982). The bimodal character of the magmatism is also reflected in the composition of the Fountain Lake Group, the occurrence of composite mafic/felsic dykes and the evidence that rocks of intermediate composition are hybrid. The intrusion of mafic sheets appears to have continued long after the emplacement of the granite plutons. Geochemically the mafic sheets appear co-magmatic with the early gabbros (Fig. 6) and quite distinct from later early Jurassic continental tholeiites (Pe-Piper et al., in press). Some have been deformed with the granite (probably in the Namurian: Waldron et al., 1989) whereas others post-dated this deformation and have yielded a Westphalian date (Pe-Piper and Piper, 1987). In these generally high-level granites, it is the mafic dykes that record continuing igneous activity during deformation along the Cobequid Fault.

A-type granites of the type found in the western Cobequids are thought to be derived by melting of anhydrous lower crust (Whalen et al., 1987). There is widespread late Proterozoic I-type plutonism in the Cobequid Highlands, including the Jeffers Brook Diorite (Pe-Piper, 1988) only $15 \mathrm{~km}$ from the North River pluton. This plutonism could have depleted the lower crust in water. The rifting of the Magdalen Basin (Durling and Marillier, 1990) has been associated with underplating of the thinned crust (Marillier and Verhoef, 1989); mafic rocks reaching higher structural levels are represented by the major gabbroic plutons of the Cobequid Highlands. These mafic magmas could have provided the heat source for melting of the lower crust.

Although there is no unequivocal evidence for strike-slip motion prior to the deformation of the pluton, the linear relationship of the many plutons along the Cobequid Fault zone and the long history of strike-slip motion on the fault suggests a genetic relationship. The apparent lack of shear deformation prior to solidification of the pluton may indicate that it formed during a period of local extension. The high structural level of many of the plutons may have led to rapid cooling and to thrust rather than 

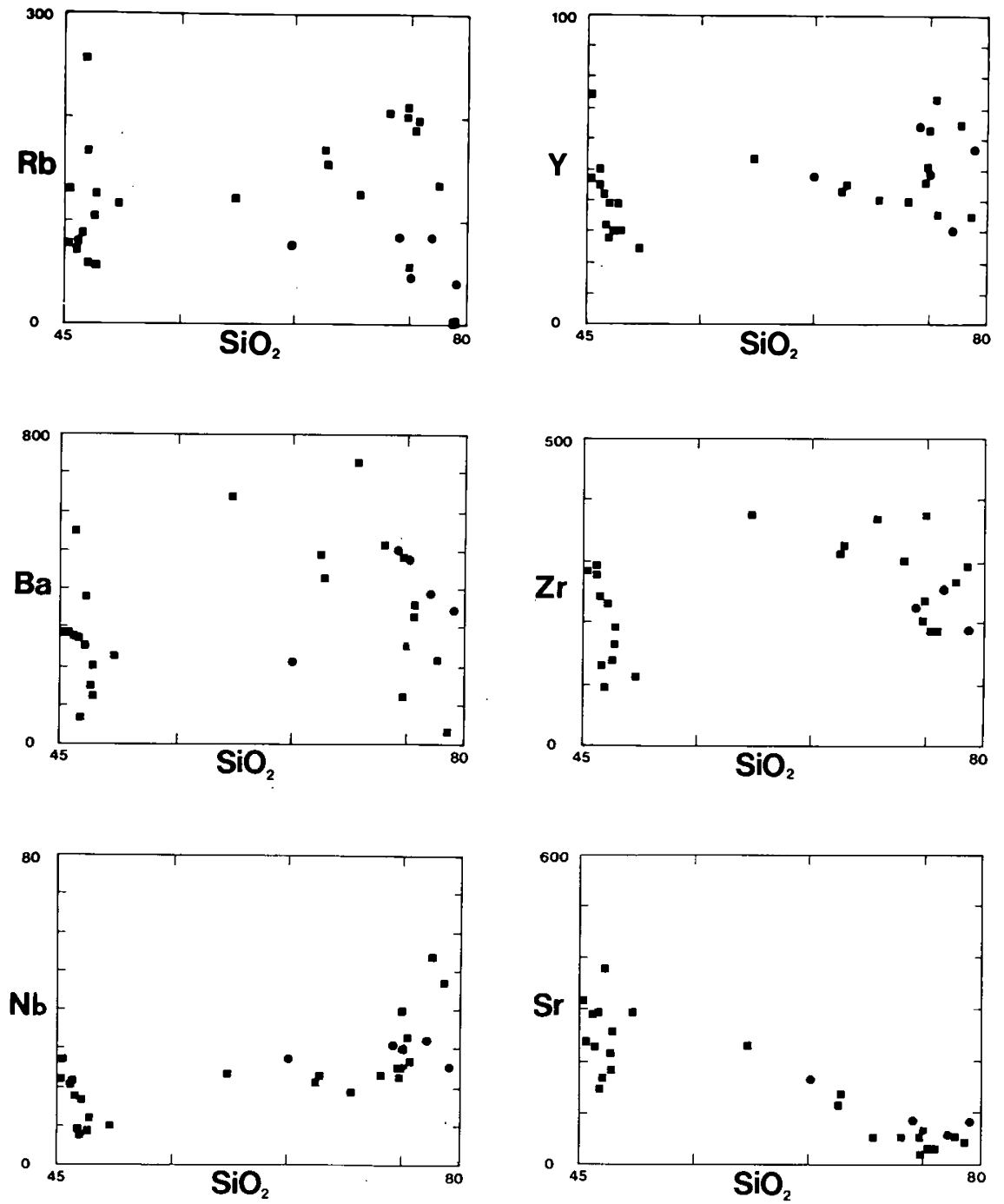

Fig. 4. Variation in selected trace elements within the North River pluton and adjacent hypabyssal rocks. Symbols as in Figure 3.

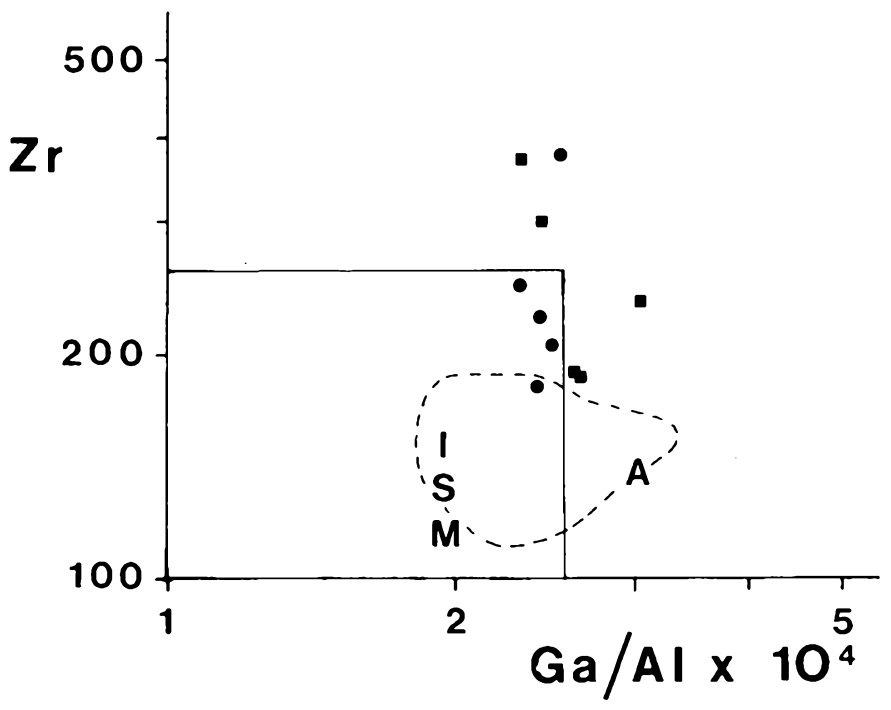

Fig. 5. Plot of $\mathrm{Zr}$ against $\mathrm{Ga} / \mathrm{Al}$ for felsic plutonic rocks (squares) and microgranite dykes (circles). Rectangular box separates A-type granites (upper right) from I, S and M-type granites (after Whalen et al., 1987). Dashed line shows limit for the Ackley pluton I-type granites (Tuach et al., 1986). strike-slip motion predominating during deformation. The weak foliation and widespread fracturing in the southern part of the North River pluton reflect further deformation associated with the Cobequid Fault zone; the dykes that cut structures related to this deformation demonstrate that it occurred within the time span of the igneous activity associated with the pluton. Slivers of highly deformed but petrographically similar granite of uncertain provenance occur along the Cobequid Fault zone to the south. Post-intrusion deformation farther west along the Cobequid Fault zone resulted in compressive deformation of the Cape Chignecto pluton (Waldron et al., 1989) and similar NW-directed thrusting associated with the Rockland Brook Fault in the Pleasant Hills pluton (Miller et al., 1990).

\section{CONCLUSIONS}

(1) The (?) upper Devonian - lower Carboniferous North River pluton is one of a series of granite and gabbro plutons intruded in the Cobequid Highlands within a regional zone of east-west strike-slip faulting associated with the Cobequid Fault.

(2) The pluton consists of a single main granite unit which intruded small marginal bodies of gabbro. Hybrid rocks of intermediate composition are developed locally. Approximately 

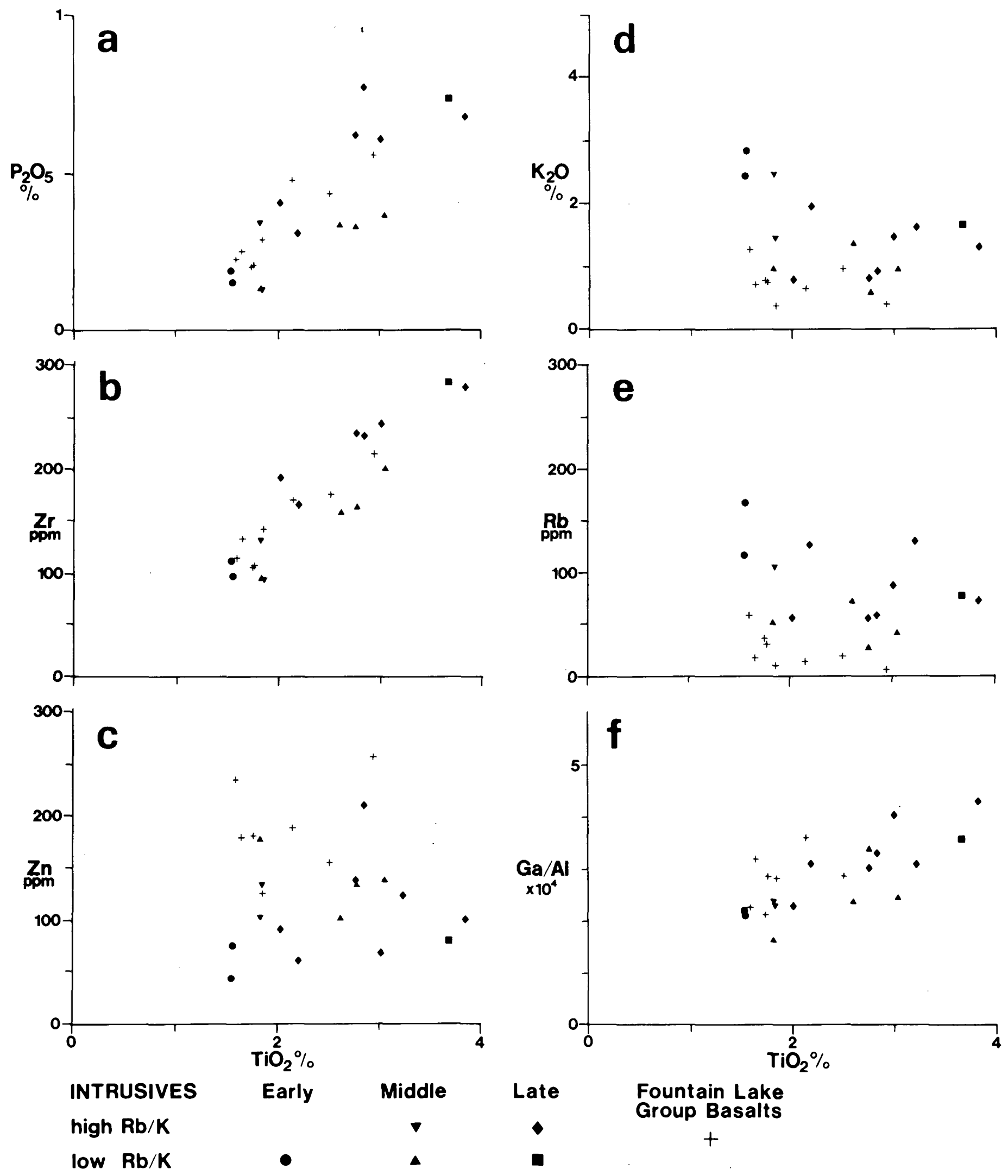

Fig. 6. Plots of selected elements against $\mathrm{TiO}_{2}$ (a proxy for degree of fractionation) for the mafic rocks of the North River pluton. Shown for comparison are Fountain Lake basalts. (a) $\mathrm{P}_{2} \mathrm{O}_{5}$; (b) $\mathrm{Zr}$; (c) $\mathrm{Zn}$; (d) $\mathrm{K}_{2} \mathrm{O}$; (e) $\mathrm{Rb}$; (f) Ga/Al. 


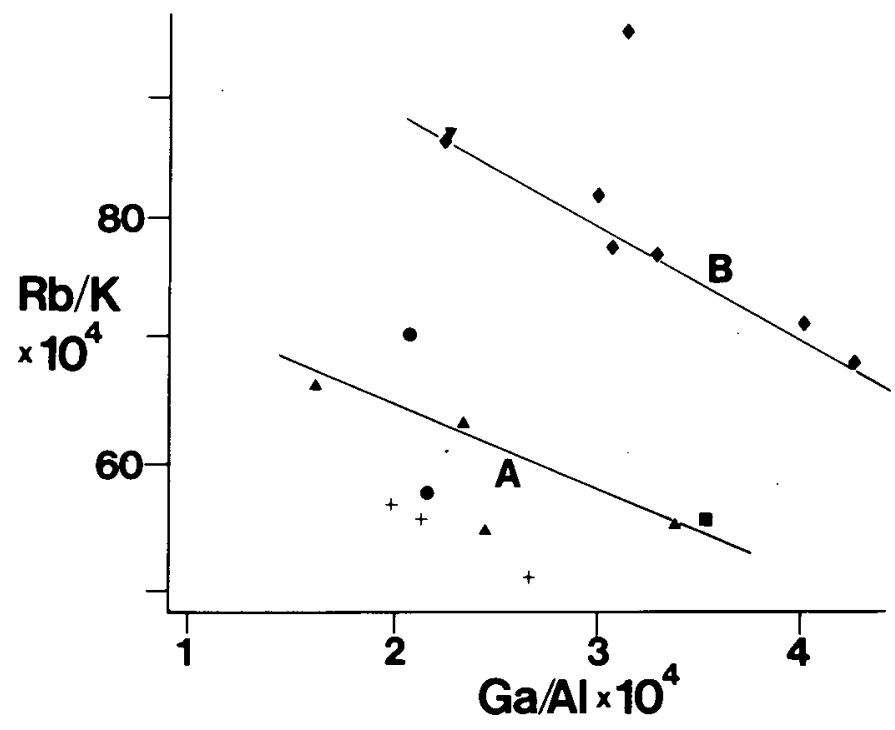

Fig. 7. Plots of Rb/K v. Ga/Al for the mafic rocks of the North River pluton, showing the recognition of assemblages with low and high $\mathrm{Rb} /$ $\mathrm{K}$ ratio (c.f. Table 1). Symbols as in Figure 6.

synchronous bimodal volcanic rocks of the Fountain Lake Group outcrop a few kilometres from the pluton.

(3) A series of diabase and microgranite sheets and dykes cut the pluton and adjacent country rock. The relative age of these sheets can be determined from their cross-cutting relationships with deformational structures in the granites. All the mafic rocks appear co-magmatic with the early gabbros and the Fountain Lake basalts, but the later mafic rocks are much more highly fractionated.

(4) All the mafic rocks appear altered, probably as the result of hydrothermal circulation of residual fluids in the cooling granites. Alteration is inhomogeneous in time and space. Enrichment in $\mathrm{Rb}$ and $\mathrm{Cs}$ relative to $\mathrm{K}$ in some mafic rocks is associated with enrichment in $\mathrm{Zr}$ and $\mathrm{P}$ relative to $\mathrm{TiO}_{2}$ and occurs only in the east-central part of the pluton. $\mathrm{K}, \mathrm{Rb}$ and $\mathrm{Cs}$ are not enriched in the Fountain Lake basalts.

(5) The hybrid rocks of intermediate composition developed particularly near the margin of the pluton through mixing, assimilation, and partial melting of penecontemporaneous mafic and felsic magmas and their crystalline products. Even where hybrid rocks are found near the marginal gabbros, they appear to be the result of mixing of more evolved mafic magmas, such as are represented by the dykes.

(6) The North River pluton differs from other published examples of plutonism in an active shear zone in that magma generation appears to have been related to regional extensional tectonics and was emplaced at a time of local extension within the shear zone, rather than the shear zone tapping a magma that originally resulted from either subduction or continental collision. Regionally, this shear zone plutonism is associated with large gabbroic plutons and intrusion of mafic dykes that persisted for tens of millions of years.

\section{ACKNOWLEDGEMENTS}

This work was supported by an NSERC operating grant. I thank D.E. Turner, G. Chinn, F.J. Boner, M. Blank, T. Coughlan and J. Nearing for help both in field and lab. I also particularly thank D.J.W. Piper for assistance in the field and review of the manuscript. J. Whalen, D.B. Clarke and J.D. Keppie also reviewed earlier drafts of the manuscript. Geochemical analyses were made at the Regional Geochemical Laboratory at Saint Mary's University.

BAILEY, E.H. and STEVENS, R.E. 1960. Selective staining of Kfeldspar and plagioclase on rock slabs and thin sections. American Mineralogist, 45, pp. 1020-1025.

CASTRO, A. 1985. The Central Extramadura batholith: geotectonic implications (European Hercynian belt). Tectonophysics, 120, pp. 57-68.

CLARKE, D.B. and MUECKE, G.K. 1985. Geochemical evolution of the South Mountain Batholith, Nova Scotia: rare-earth-element evidence. Canadian Mineralogist, 19, pp. 133-145.

DAVIES, F.B. 1982. Pan-African granite intrusion in response to tectonic volume changes in a ductile shear zone from Saudi Arabia. Journal of Geology, 90, pp. 467-483.

DOIG, R., MURPHY, J.B., NANCE, R.D., and PE-PIPER, G. 1990. U$\mathrm{Pb}$ geochronology of Precambrian rocks, eastem Cobequid Highlands, Avalon Terrane, N.S. Atlantic Geoscience Society 1990 Annual Meeting, Wolfville, Program with Abstracts, p. 12.

DONOHOE, H.V. and WALLACE, P.I. 1982. Geological map of the Cobequid Highlands, Nova Scotia. Scale 1:50 000. Nova Scotia Department of Mines and Energy.

DURLING, P.W. and MARILLIER, F.J.Y. 1990. Structural trends and basement rock subdivisions in the western Gulf of St. Lawrence, Northern Appalachians. Atlantic Geology, 26, pp. 79-95.

FLOYD, P.A. and WINCHESTER, J.A. 1975. Magma type and tectonic setting discriminations using immobile elements. Earth and Planetary Science Letters, 27, pp. 211-218.

GUINEBERTEAU, B., BOUCHEZ, J.L., and VIGNERESSE, J.L. 1987. The Mortagne granite pluton (France) emplaced by pullapart along a shear zone: structural and gravimetric arguments and regional implications. Geological Society of America Bulletin, 99, pp. 763-770.

HILDRETH, W. 1981. Gradients in silicic magma chambers: implications for lithospheric magmatism. Journal of Geophysical Research, 86, pp. 10153-10192.

HUTTON, D.H.E. 1982. A tectonic model for the emplacement of the main Donegal granite, NW Ireland. Geological Society of London Journal, 139, pp. 613-631.

HUTTON, D.H.W. 1988a. Granite emplacement mechanisms and tectonic controls: inferences from deformation studies. Royal Society of Edinburgh, Transactions, Earth Sciences, 79, pp. 245-255.

1988b. Igneous emplacement in a shear-zone termination: The biotite granite at Strontian, Scotland. Bulletin of the Geological Society of America, 100, pp. 1392-1399.

KEPPIE, J.D. 1982. The Minas geofracture. In Major structural zones and faults of the Northern Appalachians. Edited by P. St Julien and J. Beland. Geological Association of Canada, Special Paper 24, pp. 263-280. 
MARILLIER, F. and VERHOEF, J. 1989. Crustal thickness under the Gulf of St. Lawrence, northern Appalachians, from gravity and deep seismic data. Canadian Joumal of Earth Sciences, 26, pp. 1517-1532.

MILLER, B.V., NANCE, R.D., and MURPHY, J.B. 1990. Preliminary kinematic analysis of the Rockland Brook Fault, Cobequid Highlands, Nova Scotia. Geological Survey of Canada, Paper 89-1B, pp. 7-14.

MURPHY, J.B., PE-PIPER, G., NANCE, R.D., and TURNER, D. 1988. A preliminary report on geology of the eastern Cobequid Highlands, Nova Scotia. Current Research, Part B, Geological Survey of Canada, Paper 88-1B, pp. 99-107.

NICOLAS, A., BOUCHEZ, J.L., BLAISE, J., and POIRIER, J.P. 1977. Geological aspects of deformation in continental shear zones. Tectonophysics, 42, pp. 55-73.

PEARCE, J.A. and NORRY, M.J. 1979. Petrogenetic implications of Ti, $\mathrm{Zr}, \mathrm{Y}$ and $\mathrm{Nb}$ variations in volcanic rocks. Contributions to Mineralogy and Petrology, 69, pp. 33-47.

PE-PIPER, G. 1988. The calcic amphiboles of the Jeffers Brook plutonic complex, Nova Scotia. American Mineralogist, 73, pp. 993-1006.

PE-PIPER, G. and PIPER, D.J.W. 1987. The pre-Carboniferous rocks of the western Cobequid Hills, Avalon Zone, Nova Scotia. Maritime Sediments and Atlantic Geology, 25, pp. 41-48.

1989. The upper Hadrynian Jeffers Group, Cobequid Highlands, Avalon Zone of Nova Scotia: a back-arc volcanic complex. Geological Society of America Bulletin, 101, pp. 364-376.

PE-PIPER, G. and TURNER, D.S. 1988. The Hanna Farm pluton, Cobequid Highlands: petrology and significance for motion on the Kirkhill Fault. Maritime Sediments and Atlantic Geology, 24, pp. 171-183.

PE-PIPER, G., CORMIER, R.F., and PIPER, D.J.W. 1989a. The age and significance of Carboniferous plutons of the westem Cobequid Hills, Nova Scotia. Canadian Journal of Earth Sciences, 26, pp.
1297-1307.

PE-PIPER, G., MURPHY, J.B., and TURNER, D.S. 1989b. Petrology, geochemistry and tectonic setting of some Carboniferous plutons of the eastem Cobequid Hills. Atlantic Geology, 25, pp. 37-49.

PE-PIPER, G., PIPER, D.J.W., and CLERK, S.R. In press. Persistent mafic igneous activity in an A-type granite pluton, Cobequid Highlands, Nova Scotia. Canadian Journal of Earth Sciences.

STRONG, D.F. and HANMER, S.K. 1981. The leucogranites of southem Brittany: origin by faulting, frictional heating, fluid flux and fractional melting. Canadian Mineralogist, 19, pp. 163-176.

TINDLE, A.G. and PEARCE, J.A. 1981. Petrogenetic modelling of in situ fractional crystallization in the zoned Loch Doon pluton, Scotland. Contributions to Mineralogy and Petrology, 78, pp. 196207.

TAUCH, J., DAVENPORT, P.H., DICKSON, W.L., and STRONG, D.F. 1986. Geochemical trends in the Ackley Granite, southeast Newfoundland: their relevance to magmatic-metallogenic processes in high-silica granitoid systems. Canadian Joumal of Earth Sciences, 23, pp. 747-765.

WALDRON, J.G.F., PIPER, D.J.W., and PE-PIPER, G. 1989. Structural history of the Cape Chignecto pluton, Cobequid Highlands, Nova Scotia. Atlantic Geology, 25, pp. 51-62.

WHALEN, J.B. and CURRIE, K.L. 1984. The Topsails igneous terrane, Westem Newfoundland: evidence for magma mixing. Contributions to Mineralogy and Petrology, 87, pp. 319-327.

WHALEN, J.B., CURRIE, K.L., and CHAPPELL, B.W. 1987. A-type granites: geochemical characteristics, discrimination and petrogenesis. Contribution to Mineralogy and Petrology, 95, pp. 407419.

WINCHESTER, J.A. and FLOYD, P.A. 1977. Geochemical discrimination of different magma series and their differentiation products using immobile elements. Chemical Geology, 20, pp. 325-343. 